\title{
Study of Concrete Involving Use of Waste Paper Sludge Ash as Partial Replacement of Cement
}

\author{
Sajad Ahmad, M. Iqbal Malik, Muzaffar Bashir Wani, Rafiq Ahmad \\ (B.Tech Civil Engineering; Assistant professor IUST Kashmir), \\ (B.Tech Civil Engineering; Assistant professor IUST Kashmir), \\ (B.Tech Civil Engineering), \\ (B.Tech Civil Engineering; Assistant professor IUST Kashmir)
}

Figure1: Shows paper sludge ash

List of Figures and Tables:

Figure2: Shows sieved paper sludge ash

Figure3: Waste paper sludge ash added to cement for blending

Figure4: Slump cone being removed slowly.

Figure5: Compressive strength test of cube using CTM

Figure6: Cylinder specimen failing in splitting cylinder test

Figure7: Slump Value (mm)

Figure8: Variation of Compressive Strength @ 7days age

Figure9: Variation of Compressive Strength @28days age

Figure 10: 7 days Splitting Tensile Strength $\left(\mathrm{N} / \mathrm{mm}^{2}\right)$

Figure 11: 28 days Splitting Tensile Strength $\left(\mathrm{N} / \mathrm{mm}^{2}\right)$

Figure12: Water Absorbed (\%)

Figure13: Dry Density of Cube $\left(\mathrm{KN} / \mathrm{m}^{3}\right)$

\begin{abstract}
Cement manufacturing industry is one of the carbon dioxide emitting sources besides deforestation and burning of fossil fuels and concrete industry is one of the largest consumers of natural virgin materials. The global cement industry contributes about $7 \%$ of greenhouse gas emission to the earth's atmosphere. In order to address environmental effects associated with cement manufacturing and constantly depleting natural resources, there is a need to develop alternative binders to make concrete industry sustainable. This work examines the possibility of using waste paper sludge ash as partial replacement of cement for new concrete. In this study waste paper sludge ash was partially replaced as $5 \%, 10 \%, 15 \%$ and $20 \%$ in place of cement in concrete for M$25 \mathrm{mix}$ and tested for its compressive strength, tensile strength, water absorption and dry density up to 28 days of age and compared with conventional concrete. From the results obtained, it is found that Waste Paper Sludge Ash can be used as cement replacement up to $5 \%$ by weight and particle size less than $90 \mu \mathrm{m}$ to prevent decrease in workability. Further waste paper sludge has very high calorific value and could be used as a fuel before using its ash as partial cement replacement.
\end{abstract}

Keywords: - Compressive strength, Durability, split tensile strength, Waste Paper Sludge Ash Concrete, Workability

\section{INTRODUCTION}

In order to make concrete industry sustainable, the use of waste materials in place of natural resources is one of the best approaches. Paper mill sludge is a major economic and environmental problem for the paper and board industry. An enormous quantity of waste paper sludge is generated all around the world. In India, $0.7 \%$ of total urban waste generated comprises of paper sludge. UK produces over 1.5 million tons of waste paper sludge annually. Paper mill sludge is a major economic and environmental problem for the paper and board industry. The material is a by-product of the de-inking and re-pulping of paper. The main recycling and disposal routes for paper sludge are land-spreading as agricultural fertilizer, incineration in CHP plants at the paper mill, producing paper sludge ash, or disposal to landfill. The scope for landfill spreading is limited and is covered by an industry code of practice. In functional terms, paper sludge consists of cellulose fibers, fillers such as calcium carbonate and china clay and residual chemicals bound up with water. The moisture content is typically up to $40 \%$. The material is viscous, sticky and hard to dry and can vary in viscosity and lumpiness. It has an energy content that makes it a useful candidate as an alternative fuel for the manufacture of Portland cement. Paper sludge is currently in use as an alternative fuel. It is classified as Class 2 (liquid alternative fuels) in the Cembureau classification of alternative fuels. After incinerating paper sludge at approximately $800{ }^{\circ} \mathrm{C}$, the 
resultant fly ash may contain reactive silica and alumina (in the form of metakaolin) as well as lime $(\mathrm{CaO})$ which contributes chemically to the Portland cement ingredients. Paper sludge ash is therefore potentially suitable as an ingredient in:

- the cement kiln feed, contributing calcium, silica and alumina.

- the manufacture of blended cements.

This research will summarize the behavior of concrete with the waste paper sludge ash by replacement of cement in the range of 5\%,10\%,15\% and $20 \%$ which may help to reduce the disposal problem of sludge and enhance the properties of concrete. As wastepaper sludge ash contains higher percentage of silicon dioxide $\mathrm{SiO}_{2}$, it may provide extra strength to concrete. This project will try to study the design parameters of concrete on inclusion of waste paper as partial replacement of cement.

\subsection{Cement and Aggregates}

\section{MATERIALS USED}

Khyber ordinary Portland cement of 43 grade confining to IS 8112 was used throughout the work. Fine aggregates used throughout the work comprised of clean river sand with maximum size of $4.75 \mathrm{~mm}$ conforming to zone II as per IS383-1970 with specific gravity of 2.6. Coarse aggregates used consisted of machine crushed stone angular in shape passing through $20 \mathrm{~mm}$ IS sieve and retained on $4.75 \mathrm{~mm}$ IS sieve with specific gravity of 2.7 .

\subsection{Waste paper Sludge Ash (WSA)}

Waste paper sludge was obtained from JML waste paper corporation, Pathankot, Punjab, India. It was then sun dried and incinerated so as to convert it into ash. The ash was sieved through 90 micron $(90 \mu \mathrm{m})$ Indian Standard sieve. The specific gravity of waste paper sludge ash was found to be 2.6.Chemical composition of paper sludge ash is presented in TABLE 1.Fig.1 shows waste paper sludge ash, Fig.2 shows sieved paper sludge ash and Fig. 3 shows mixing of paper sludge ash with cement.

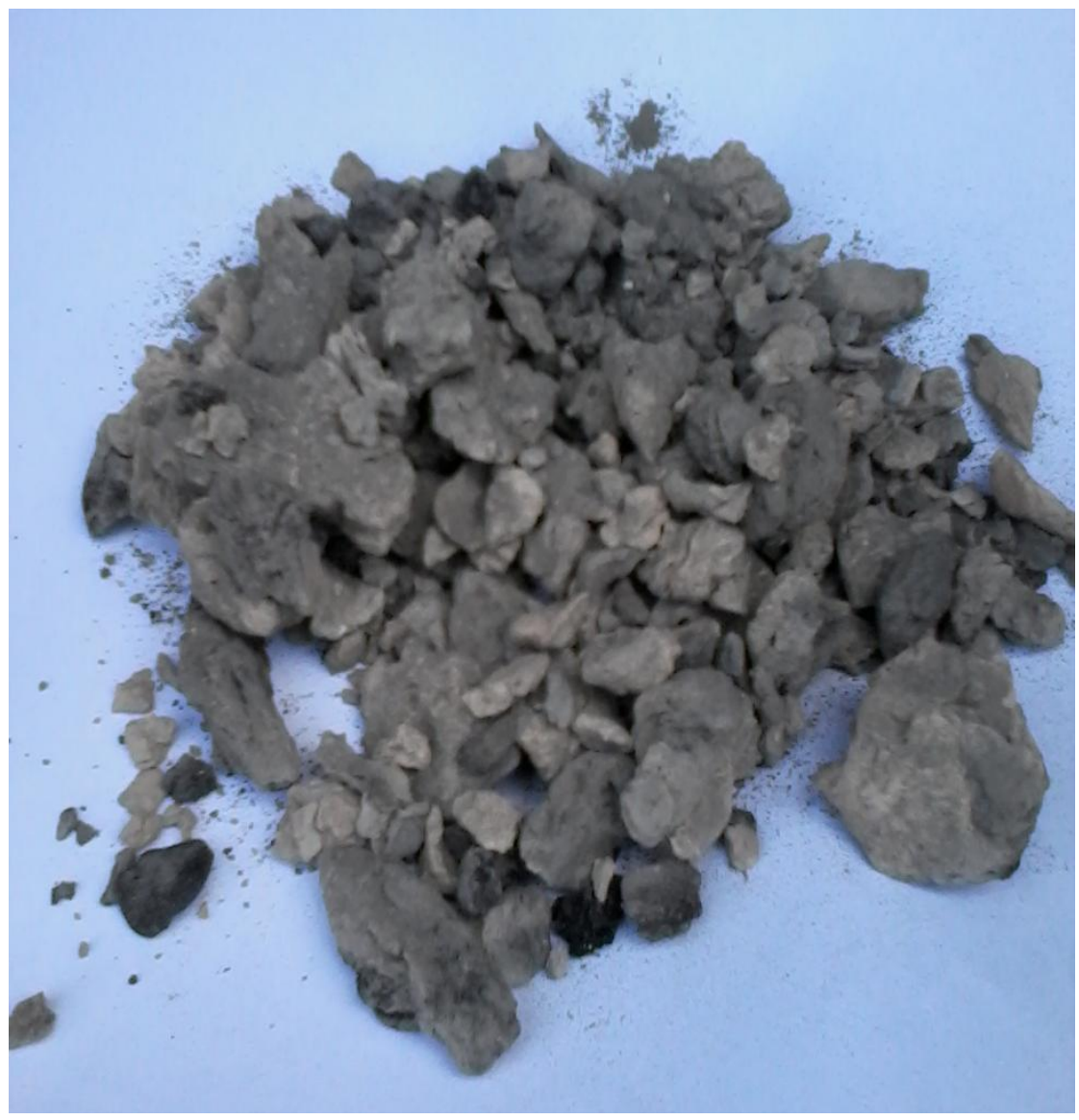

Fig.1: Waste Paper Sludge Ash 
Table 1. Chemical composition of waste paper sludge ash

\begin{tabular}{|c|c|}
\hline Element & Percentage Content \\
\hline O & 15.83 \\
\hline Ca & 14.94 \\
\hline Si & 60.57 \\
\hline Al & 2.06 \\
\hline Mg & 3.59 \\
\hline S & 1.07 \\
\hline K & 0.16 \\
\hline Fe & 0.92 \\
\hline Na & 0.22 \\
\hline
\end{tabular}

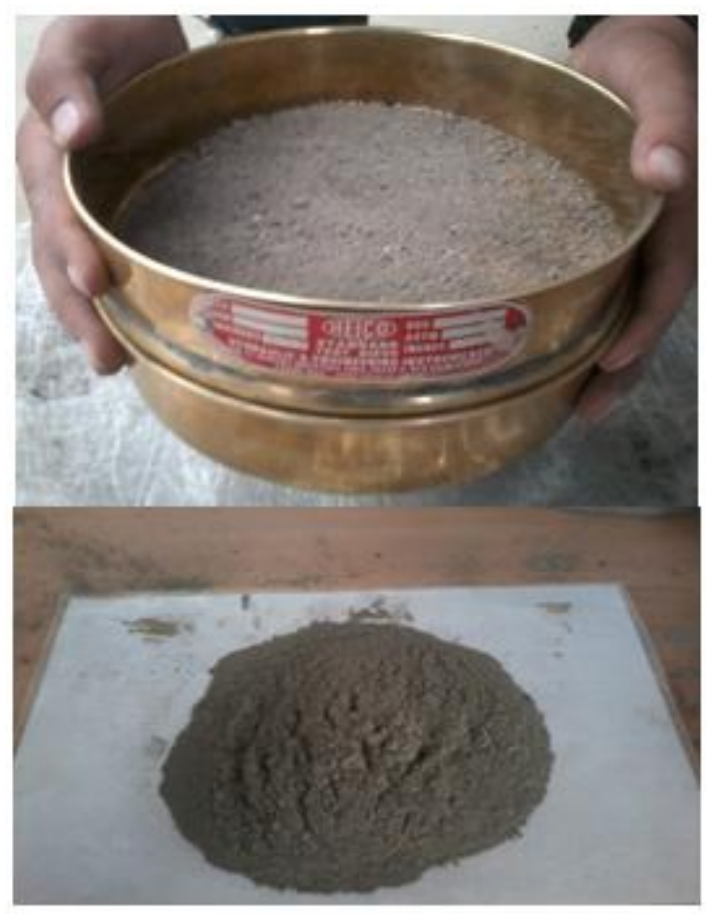

Fig. 2: Sieving of waste paper sludge ash

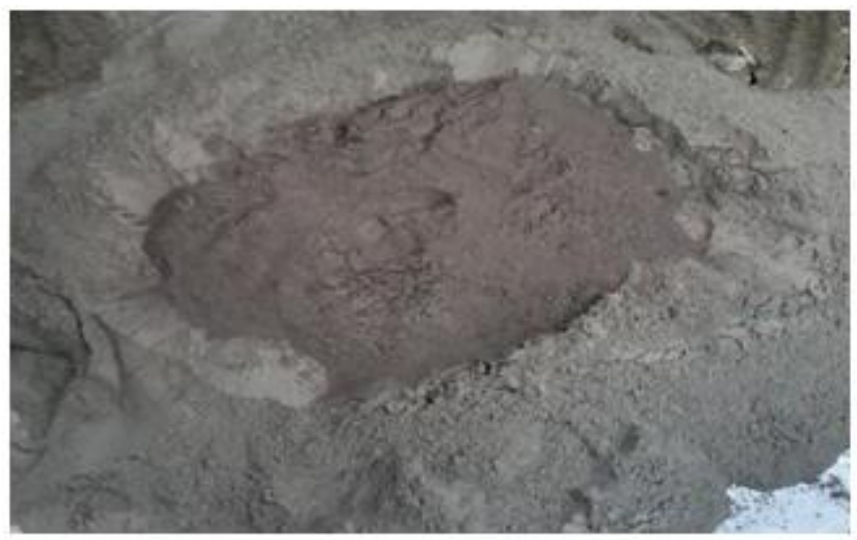

Fig.3: Waste paper sludge ash added to cement for blending 


\section{EXPERIMENTAL INVESTIGATION}

3.1. Mix Proportion

The concrete mix design was proposed by using IS 10262 . The grade of concrete used was M-25 with water to cement ratio of 0.45 . The mixture proportions used in laboratory for experimentation are shown in TABLE 2.

Table 2: Mix Proportions

\begin{tabular}{|c|c|c|c|c|c|c|c|}
\hline $\begin{array}{c}\text { Paper } \\
\text { Sludge } \\
\text { Ash \% }\end{array}$ & $\begin{array}{c}\text { w/c } \\
\text { ratio }\end{array}$ & $\begin{array}{c}\text { Water } \\
\left(\mathrm{Kg} / \mathrm{m}^{3}\right)\end{array}$ & $\begin{array}{c}\text { Cement } \\
\left(\mathrm{Kg} / \mathrm{m}^{3}\right)\end{array}$ & $\begin{array}{c}\text { Fine } \\
\text { Aggregate } \\
\left(\mathrm{Kg} / \mathrm{m}^{3}\right)\end{array}$ & $\begin{array}{c}\text { Paper } \\
\text { Sludge Ash } \\
\left(\mathrm{Kg} / \mathrm{m}^{3}\right)\end{array}$ & $\begin{array}{c}\text { Coarse } \\
\text { Aggregate } \\
\left(\mathrm{Kg} / \mathrm{m}^{3}\right)\end{array}$ & $\begin{array}{c}\text { Slump } \\
(\mathrm{mm})\end{array}$ \\
\hline 0 & 0.45 & 191.6 & 425.80 & 543.5 & 0.00 & 1199.36 & 25 \\
\hline 5 & 0.45 & 191.6 & 404.51 & 543.5 & 21.29 & 1199.36 & 24 \\
\hline 10 & 0.45 & 191.6 & 383.22 & 543.5 & 42.58 & 1199.36 & 20 \\
\hline 15 & 0.45 & 191.6 & 361.93 & 543.5 & 63.87 & 1199.36 & 16 \\
\hline 20 & 0.45 & 191.6 & 340.64 & 543.5 & 85.16 & 1199.36 & 13 \\
\hline
\end{tabular}

\subsection{Test on Cement}

Consistency Test was performed on cement using Vicat's Apparatus so as to determine the water-cement ratio.

\subsection{Test on Fresh Concrete}

3.2.1. Slump Test The workability of all concrete mixtures was determined through slump test utilizing a metallic slump mould. The difference in level between the height of mould and that of highest point of the subsided concrete was measured (Fig.3) and reported as slump. The slump tests were performed according to IS 1199-1959.

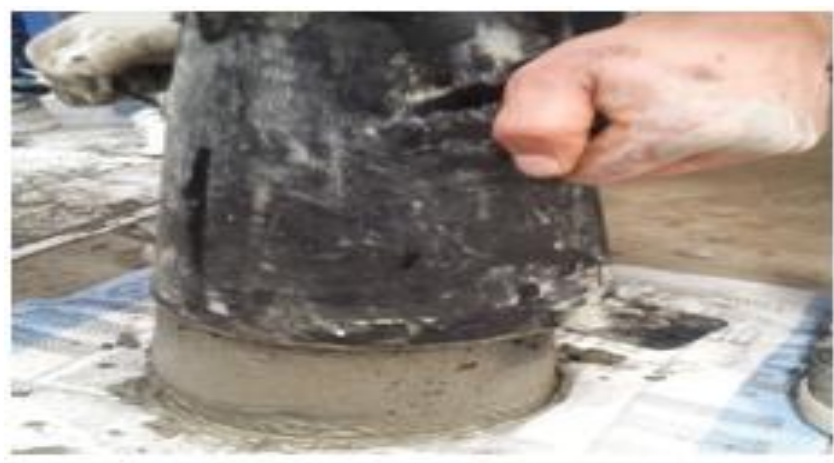

Fig.4: Slump cone being removed slowly.

\subsection{Tests on hardened concrete}

From each concrete mixture, cubes of size $150 \mathrm{~mm}$ x $150 \mathrm{~mm}$ x $150 \mathrm{~mm}$ and $150 \mathrm{~mm}$ x $300 \mathrm{~mm}$ cylinders have been casted for the determination of compressive strength (Table 3) and splitting tensile strength (Table 4) respectively (Fig.4 \& 5). The concrete specimens were cured under normal conditions as per IS 516-1959 and were tested at 7 days and 28days for determining compressive strength as per IS 516-1959 and splitting tensile strength as per IS 5816-1999.

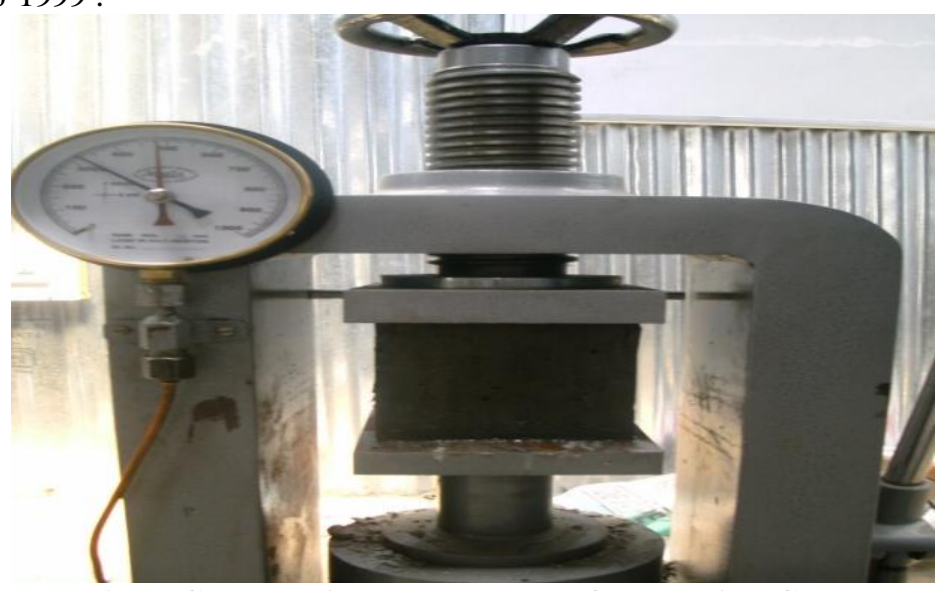

Fig.5: Compressive strength test of cube using CTM 


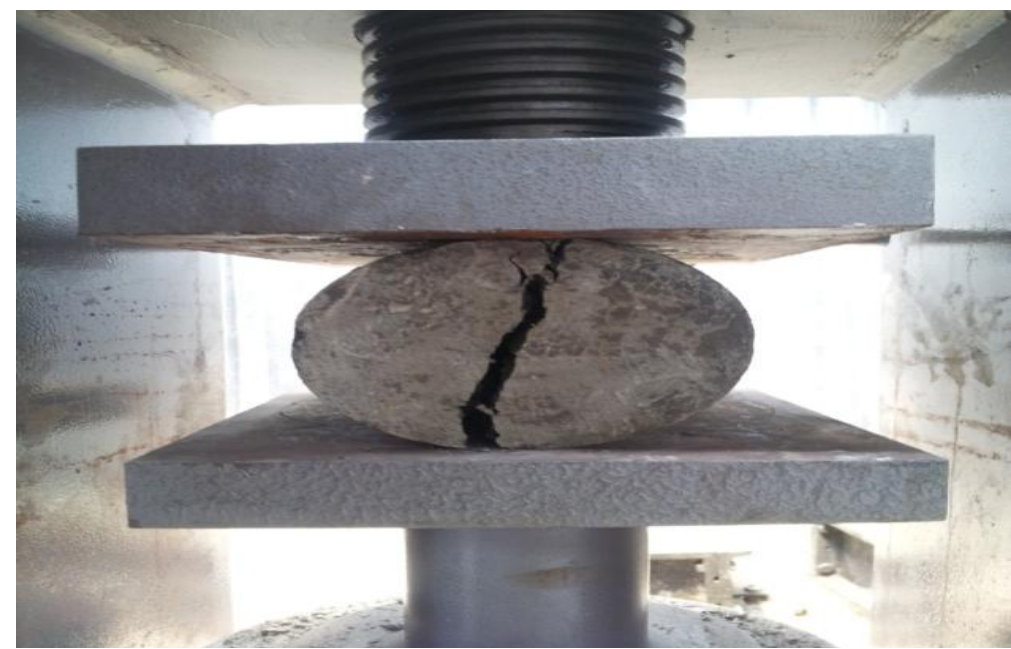

Fig. 6. Cylinder specimen failing in splitting cylinder test

Table 3: Compressive Strength Test results for cube specimens of size $150 \mathrm{~mm}$ x $150 \mathrm{~mm}$ x 150mm

\begin{tabular}{|c|c|c|c|c|c|}
\hline $\begin{array}{c}\text { S. } \\
\text { No. }\end{array}$ & $\begin{array}{c}\text { Paper } \\
\text { Sludge } \\
\text { Ash } \\
\%\end{array}$ & $\begin{array}{c}\text { Avg. } \\
\text { load @ } \\
7 \text { days } \\
\text { (KN) }\end{array}$ & $\begin{array}{c}\text { Avg. Load } \\
\text { @ 28 } \\
\text { days(KN) }\end{array}$ & $\begin{array}{c}\text { Avg. } \\
\text { Compressive } \\
\text { Strength @ 7 } \\
\text { days(N/mm }{ }^{2}\end{array}$ & $\begin{array}{c}\text { Avg. } \\
\text { Compressive } \\
\text { Strength @ 28 } \\
\text { days(N/mm }{ }^{2}\end{array}$ \\
\hline 1 & 0 & 483 & 633 & 21.48 & 28.07 \\
\hline 2 & $5 \%$ & 513 & 657 & $\mathbf{2 3 . 6 2 8}$ & $\mathbf{3 2 . 3 4 3}$ \\
\hline 3 & $10 \%$ & 453 & 593 & 20.15 & 26.29 \\
\hline 4 & $15 \%$ & 403 & 557 & 17.92 & 24.74 \\
\hline 5 & $20 \%$ & 345 & 498 & 15.14 & 22.147 \\
\hline
\end{tabular}

Table 4: Splitting Tensile Strength Test results of $150 \mathrm{~mm} \times 300 \mathrm{~mm}$ cylinders

\begin{tabular}{|c|c|c|c|c|c|}
\hline $\begin{array}{c}\text { S. } \\
\text { No. }\end{array}$ & $\begin{array}{c}\text { Paper } \\
\text { Sludge } \\
\text { Ash } \\
\%\end{array}$ & $\begin{array}{c}\text { Avg. } \\
\text { load @ } \\
7 \text { days } \\
(\mathrm{KN})\end{array}$ & $\begin{array}{c}\text { Avg. Load } \\
\text { @ 28 } \\
\text { days(KN) }\end{array}$ & $\begin{array}{c}\text { Avg. Split } \\
\text { Tensile } \\
\text { Strength @7 } \\
\text { days(N/mm }\end{array}$ & $\begin{array}{c}\text { Avg. Split } \\
\text { Tensile Strength } \\
@ 28 \\
\text { days(N/mm }\end{array}$ \\
\hline 1 & 0 & 150 & 180 & 2.122 & 2.546 \\
\hline 2 & $5 \%$ & 157 & 190 & $\mathbf{2 . 2 2 5}$ & $\mathbf{2 . 6 8 8}$ \\
\hline 3 & $10 \%$ & 153 & 177 & 2.157 & 2.510 \\
\hline 4 & $15 \%$ & 145 & 165 & 2.051 & 2.334 \\
\hline 5 & $20 \%$ & 125 & 150 & 1.768 & 2.122 \\
\hline
\end{tabular}

\subsection{Water absorption test}

The average dry weight of cube specimens after removing from moulds was measured and the average weight of cube specimens after submerging in water for curing was measured at 28 days of age (Table 5). The percentage of water absorption was measured for each concrete specimen and it gave indirect measure of durability.

Table 5: Water Absorption Test results for cube specimens of size $150 \mathrm{~mm}$ x 150 $\mathrm{mm}$ x 150mm

\begin{tabular}{|c|c|c|c|c|c|}
\hline $\begin{array}{c}\text { S. } \\
\text { No. }\end{array}$ & $\begin{array}{c}\text { Paper Sludge } \\
\text { Ash \% }\end{array}$ & $\begin{array}{c}\text { Dry weight } \\
\text { of cube (gm) }\end{array}$ & $\begin{array}{c}\text { Wet weight } \\
\text { of cube (gm) }\end{array}$ & $\begin{array}{l}\text { Water } \\
\text { absorbed (gm) }\end{array}$ & $\begin{array}{c}\text { Percentage water } \\
\text { absorption }\end{array}$ \\
\hline 1 & 0 & 8382 & 8280 & 98 & $1.17 \%$ \\
\hline 2 & $5 \%$ & 8352 & 8456 & 104 & $1.245 \%$ \\
\hline 3 & $10 \%$ & 8225 & 8340 & 115 & $1.398 \%$ \\
\hline 4 & $15 \%$ & 8115 & 8241 & 126 & $1.552 \%$ \\
\hline 5 & $20 \%$ & 7998 & 8135 & 137 & $1.713 \%$ \\
\hline
\end{tabular}




\subsection{Light weight character}

The average dry weight of concrete cube specimens containing 5\%,10\%, 15\% and $20 \%$ waste paper sludge ash in place of cement by weight was compared with average dry weight of normal M-25 concrete cube specimens and the percentage decrease in dry weight was measured (Table 6).

Table 6: Dry Weight Density results for cube specimens of size 150mm x 150mm x 150mm

\begin{tabular}{|c|c|c|c|c|}
\hline $\begin{array}{c}\text { S. } \\
\text { No. }\end{array}$ & $\begin{array}{c}\text { Paper Sludge } \\
\text { Ash } \\
\%\end{array}$ & $\begin{array}{c}\text { Avg. Dry } \\
\text { weight of } \\
\text { cube }(\mathrm{gm})\end{array}$ & $\begin{array}{c}\text { Avg. dry density } \\
\text { of cube }\left(\mathrm{KN} / \mathrm{m}^{3}\right)\end{array}$ & $\begin{array}{l}\text { Percentage change in } \\
\text { weight as compared to } \\
\text { reference }(\%)\end{array}$ \\
\hline 1 & 0 & 8382 & 24.83 & $0 \%$ \\
\hline 2 & $5 \%$ & 8352 & 24.75 & $-0.358 \%$ \\
\hline 3 & $10 \%$ & 8225 & 24.37 & $-1.870 \%$ \\
\hline 4 & $15 \%$ & 8115 & 24.04 & $-3.185 \%$ \\
\hline 5 & $20 \%$ & 7998 & 23.70 & $-4.580 \%$ \\
\hline
\end{tabular}

\section{RESULTS AND DISCUSSION}

\subsection{Fresh concrete}

The slump values of all the mixtures are represented in TABLE 2. The slump decreased with the increase in waste paper sludge ash content. Waste paper sludge ash particles absorbed more water as compared to cement and thus decreasing the workability of concrete mix. Slump was maximum for the concrete mixture containing 5\% waste paper sludge ash in place of cement. The variation of slump with waste paper sludge ash content is depicted in Fig. 7.

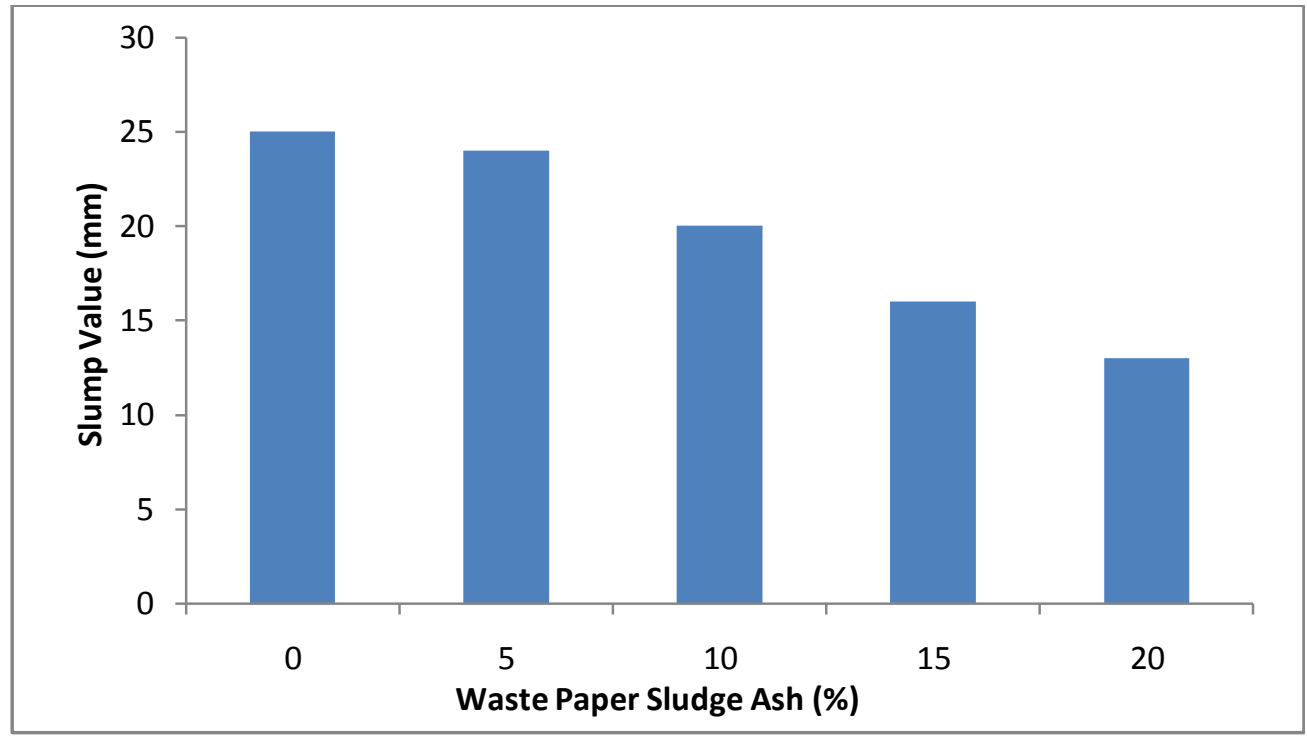

Fig.7: Slump Value (mm)

\subsection{Hardened concrete}

The compressive strength tests and splitting tensile strength tests are presented in TABLES $3 \& 4$ respectively. Compressive strength tests and splitting tensile strength tests were carried out at 7 and 28 days. An increase in compressive strength was observed at 5\% replacement of cement by waste paper sludge ash and there after decreasing. The maximum compressive strength measured was $15 \%$ more than that of reference mix at 28 days corresponding to concrete mix containing $0 \%$ waste paper sludge ash in place of cement. Compressive strength for concrete mix with 10\%, $15 \%$ and $20 \%$ waste paper sludge ash content was found to be less than that of reference mix. Splitting tensile strength was found to be more than that for reference mix at 5\% cement replacement. Splitting tensile strength decreased with increasing waste paper sludge ash content. Fig. 8 and 9 present compressive strength of all mixtures at 7 and 28 days respectively. Fig. 10 and 11 present splitting tensile strength of all mixtures at 7 and 28 days respectively. 


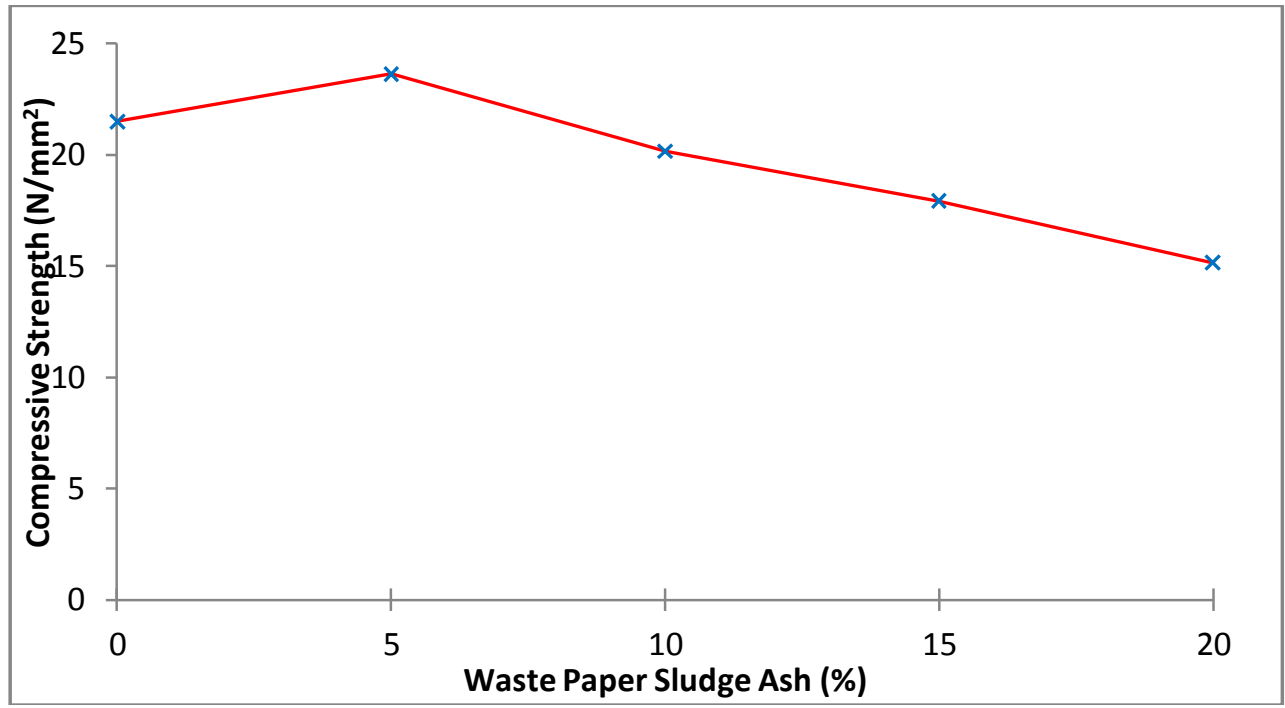

Fig.8: Variation of Compressive Strength @ 7days age

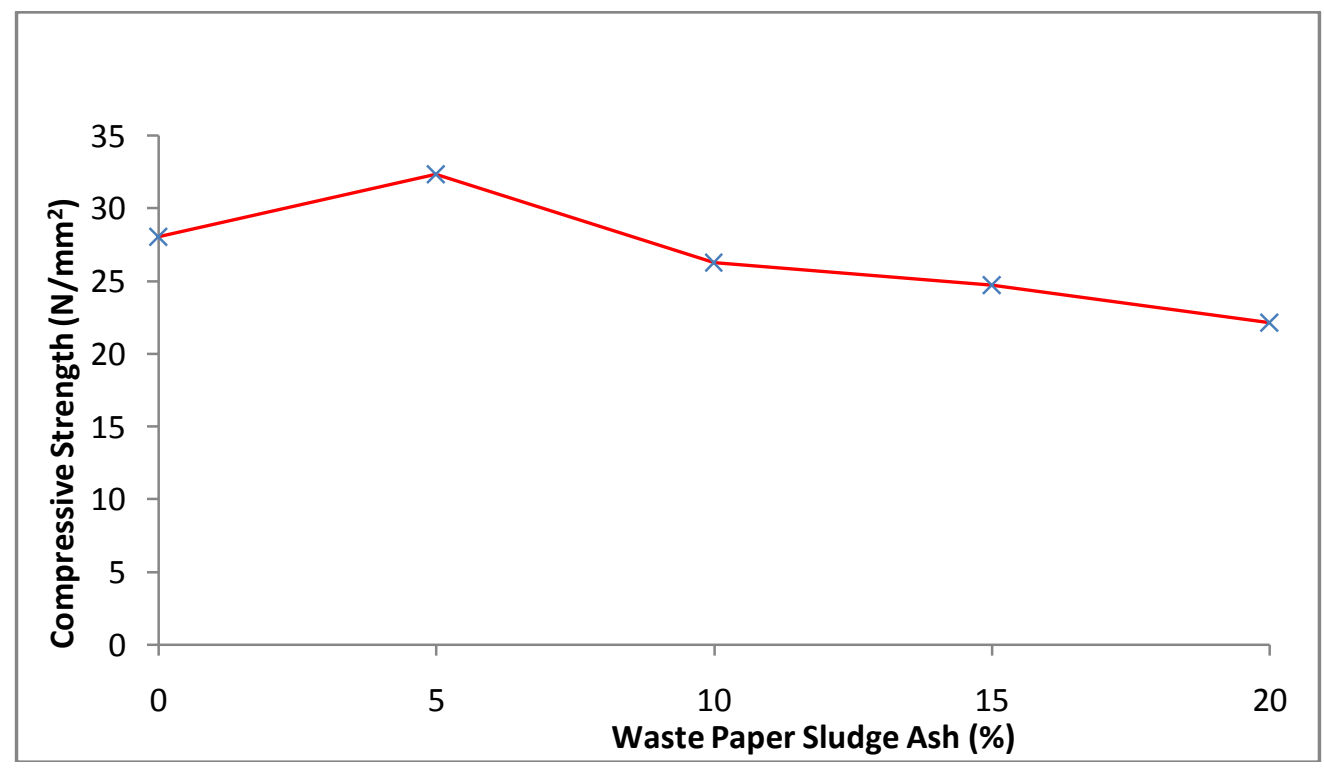

Fig.9: Variation of Compressive Strength @ 28days age

Fig.10: 7 days Splitting Tensile Strength $\left(\mathrm{N} / \mathrm{mm}^{2}\right)$

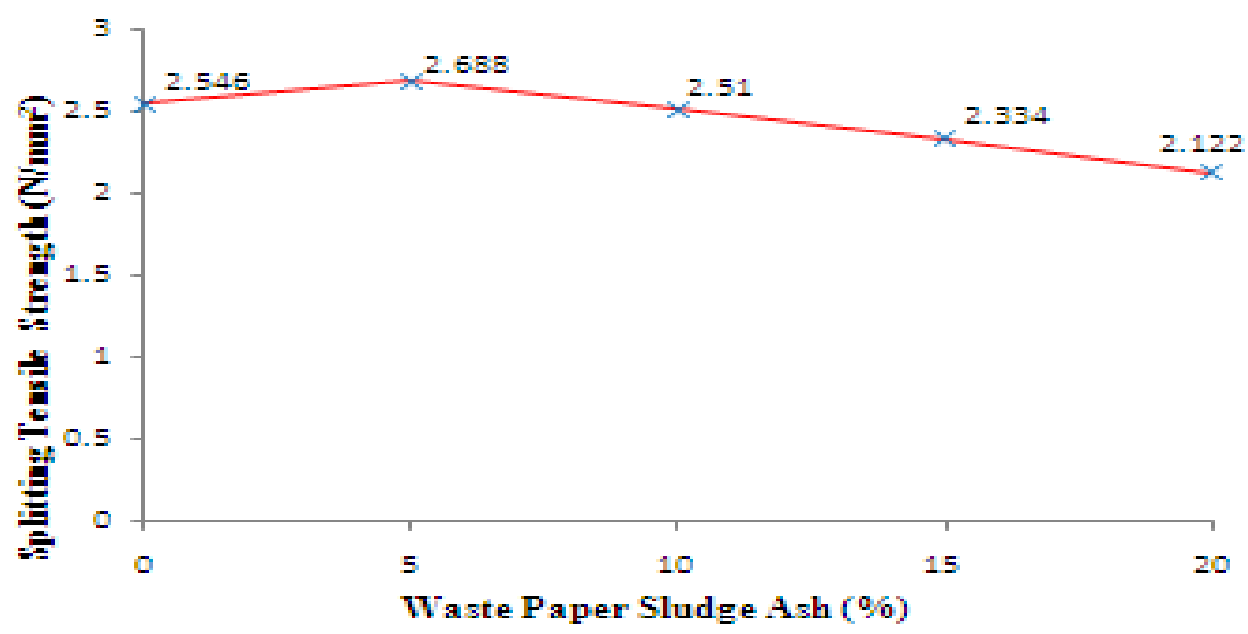




\subsection{Water absorption}

Water absorption test was carried out for all mixtures and percentage water absorption was measured. The percentage water absorption increased with increase in waste paper sludge ash content. The lowest value of water absorption was found for concrete mix with 5\% waste paper sludge ash content. TABLE 5 \& Fig.12 depicts the percentage water absorption for all mixtures.

Fig.11: 28 days Splitting Tensile Strength $\left(\mathrm{N} / \mathrm{mm}^{2}\right)$

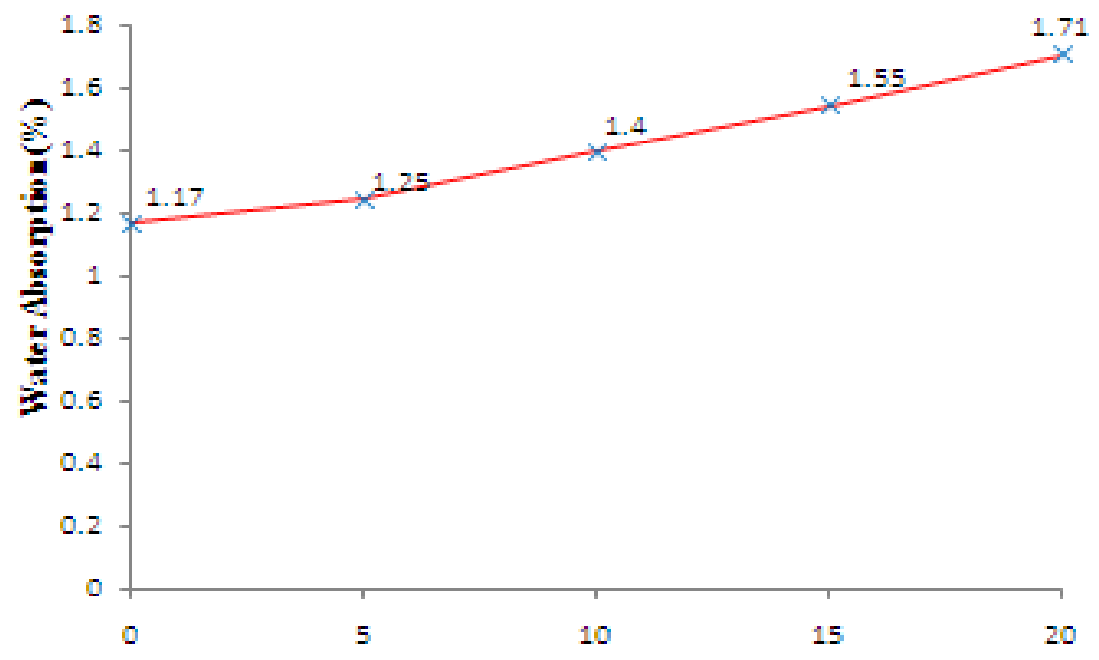

\subsection{Light weight character}

Average dry weight of cube specimens of each mixture as compared to reference mix was studied and it was observed that density decreased with increase in waste paper sludge ash content. The results showed $4.58 \%$ reduction in dry weight of concrete cube specimens for concrete mix with $20 \%$ waste paper sludge ash content as compared to reference mix.This reduction in density can be attributed to lesser specific gravity of waste paper sludge ash as compared to cement. Thus, waste paper sludge ash concrete is light weight in nature. TABLE $6 \&$ Fig. 13 depicts the value of dry density and percentage change in dry weight with respect to reference mix.

Fig.12: Water Absorbed (\%)

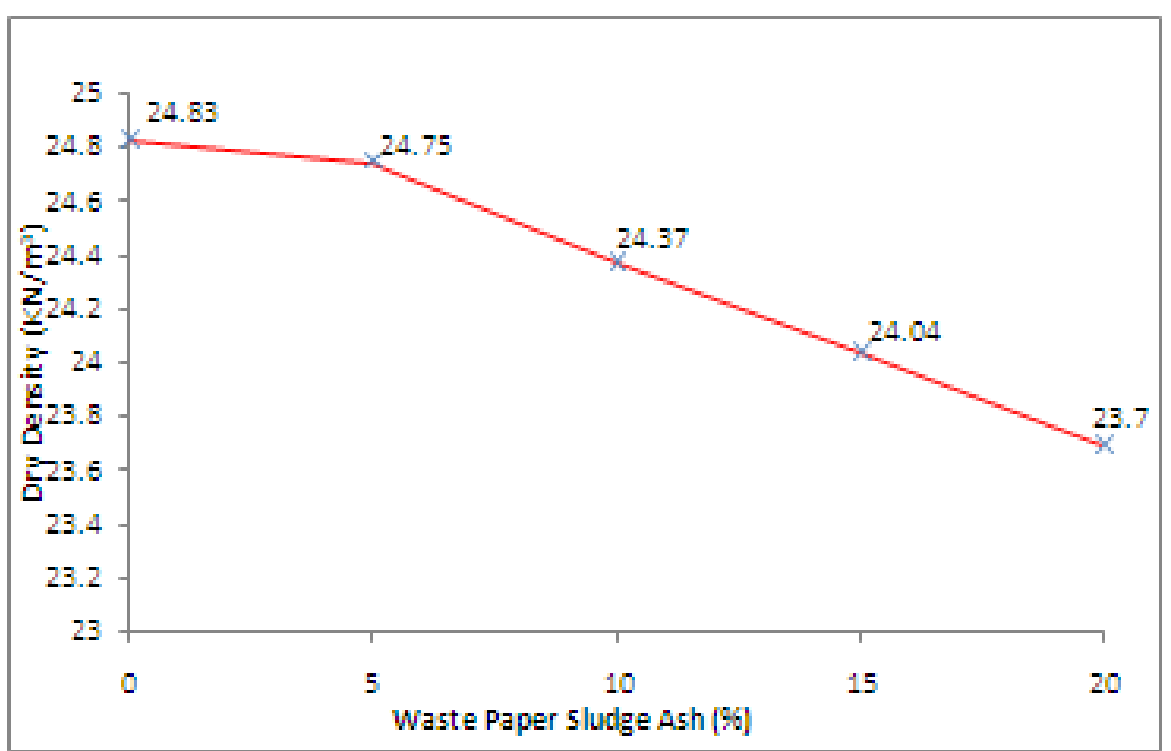


Fig.13: Dry Density of Cube $\left(\mathrm{KN} / \mathrm{m}^{3}\right)$

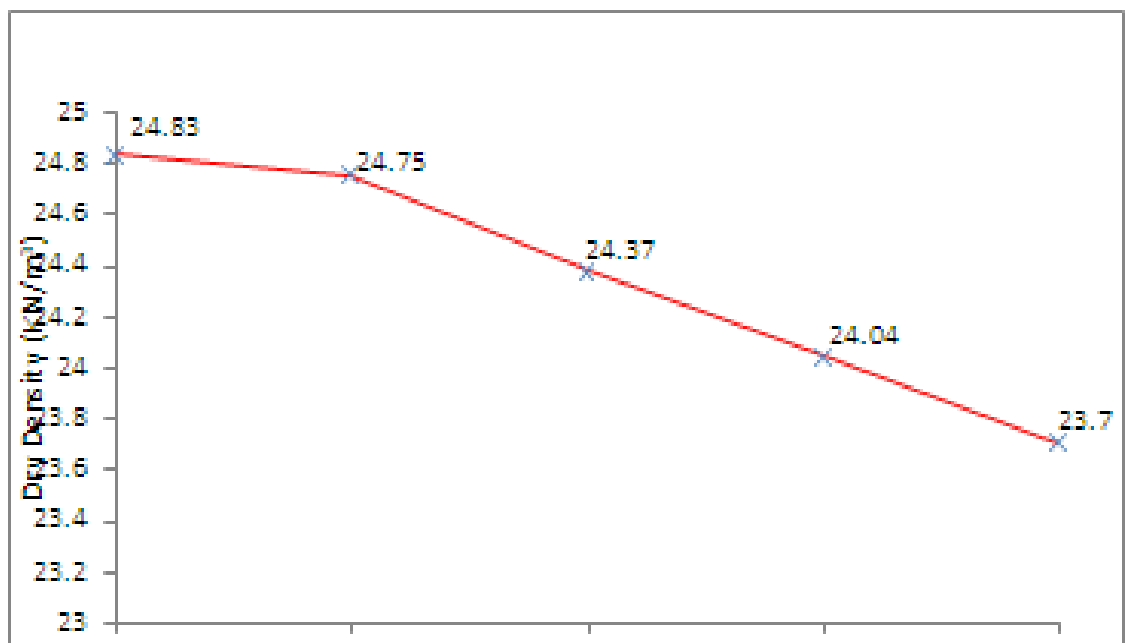

\section{CONCLUSION}

On the basis of results obtained, following conclusions can be drawn:

1. 5\% replacement of cement by waste paper sludge ash showed $10 \%$ increase in compressive strength at 7 days and $15 \%$ increase in compressive strength at 28 days.

2. Cement in concrete can be replaced by waste paper sludge ash up to $5 \%$ by weight showing $15 \%$ increase in compressive strength at 28 days.

3. With increase in waste paper sludge ash content, percentage water absorption increases.

4. With increase in waste paper sludge ash content, average weight decreases by $4.58 \%$ for mixture with $20 \%$ waste paper sludge ash content thus making waste paper sludge ash concrete light weight.

5. Workability of concrete mix decreases with increase in waste paper sludge ash content.

6. Splitting tensile strength decreases with increase in waste paper sludge ash content and is more than reference concrete at $5 \%$ replacement.

7. Use of waste paper sludge ash in concrete can prove to be economical as it is non useful waste and free of cost.

8. Use of waste paper sludge ash in concrete will eradicate the disposal problem of waste paper sludge ash ,reduce emission of harmful pollutants by cement manufacture industry into our environment and thus prove to be environment friendly, paving way for greener concrete.

9. Use of waste paper sludge ash in concrete will preserve natural resources that are used for cement manufacture and thus make concrete construction industry sustainable and waste paper sludge can be used as fuel before using its ash in concrete for partial cement replacement and also the disposal problem for paper industries for this waste material is fully solved.

\section{ACKNOWLEDGEMENTS}

The authors are thankful to Dr. J. A. Naqash, Associate Professor, Department of Civil Engineering, National Institute of Technology, Srinagar, J\&K, India and Er. M. Iqbal Mirza, Assistant Professor, Department of Civil Engineering, Islamic University of Science and Technology, Awantipora, J\&K, India and Dr. Shakeel Ahmad Engineering Geologist JKSPDC Srinagar J\&K India.

\section{REFERENCES}

[1] A S Rossomagina, D V Saulin, and I S Puzanov. (2002). Prevention of Alkali-Silica Reaction in Paper Sludge Ash \& Glass Aggregate Concrete.Perm State Technical University, Russia . 102 (1), 2.

[2] Shayan and A. Xu. (Jan.2009). Value added utilization of waste paper in concrete . Cement and Concrete Research. 44 (1), 81-89.

[3] Asoka Pappu, Mohini Saxena, and Shyan R. Asolekar. (2002). Solid Waste Generation In India And Their Recycling Potential In Building Materials. Regional Research Institute (CSIR) and IIT Bombay, India. 1 (2), 12-20.

[4] B.S. Mohammed, O.C. Fang. (2011). Mechanical and durability properties of concretes containing papermill residuals and fly ash.Construction and Building Materials. 25 (1), 717-725 . 
[5] Carpenter, A. J. and Cramer, C.M. (1999). Mitigation of ASR in pavement patch concrete that incorporates highly reactive fine aggregate . Transportation Research Record 1668. 99 (1087), 60-67.

[6] Vegas, J. Urreta,et.al. (August 2009). Freezethaw resistance of blended cement containing calcined paper . Construction and Building Materials. 23 (8), 45-55.

[7] IS (Indian Standard) (1959) IS 1199-1959: Methods of Sampling and Analysis of Concrete, Bureau of Indian Standards, New Delhi

[8] IS (Indian Standard) (1959) IS 516-1959: Methods of Tests for Strength of Concrete, Bureau of Indian Standards, New Delhi

[9] IS (Indian Standard) IS 10262-1982: Recommended Guidelines for Concrete Mix Design, Bureau of Indian Standards, New Delhi

[10] Pera, J. and Amrouz, A.. (1998). Development of highly reactive metakaolin from paper sludge. Advanced Cement Based Materials. 7 (1), 49-56.

[11] R. Srinivasan, K. Sathiya, and M. Palanisamy. (2010). Experimental investigation in developing low cost concrete from paper industry waste. The Bulletin of the Polytechnic Institute of Jassy, Construction Architecture Section (Romania). 111 (3), 34-35.

[12] R.S. Gallardo, Mary Ann Q Adajar (December 2006). Structural performance of concrete with paper sludge as fine aggregates partial replacement enhanced with admixtures. In: Symposium on Infrastructure Development and the Environment, December 2006, University of the Philippines. pp. 1-60

[13] T.R. Naik, T. Friberg, and Y. Chun. (December 2003). Use of pulp and paper mill residual solids in production of cellucrete, College of Engineering and Applied Science . University of Wisconsin, USA. 11 (112), 18-30.

[14] T.R. Naik, Y. Chun, and R.N. Kraus. (2003). Use of residual solids from pulp and paper mills for enhancing strength and durability of ready-mixed concrete. US Dept. of Energy. DE-FC07 (00ID13867), $1-40$.

[15] T.R. Naik, Y. Chun, and R.N. Kraus. (2005). Paper industry fibrous residuals in concrete and CLSM. Department of Civil Engineering and Mechanics, The University of Wisconsin-Milwaukee. CBU2005 (10), 1-70.

[16] T.R. Naik. (July 2005). Concrete with paper industry fibrous residuals: mixture . ACI Materials Journal. $102(4), 237-243$.

[17] V. Mymrin, A.M.C. Ferreira, et. al. (September 2009). Paper production sludge application for producing of new construction materials. In: Symposium on Infrastructure Development and the Environment, September 2009, Bath, UK. pp. 6-9

[18] Y. Chun, T.R. Naik, and R.N. Kraus (July $11-13$, 2005). Durable concrete through use of pulp and paper mill residuals, composites in construction. In: Third international conference, July $11-13,2005$, Lyon, France. pp. 6-9. 